Kansas State University Libraries

New Prairie Press

\title{
RESPONSE OF SOYBEAN YIELD AND YIELD COMPONENTS TO PHOSPHORUS FERTILIZATION IN SOUTH DAKOTA
}

Adams Kusi Appiah

South Dakota State University

Rebecca Helget

South Dakota State University

Yi Xu

South Dakota State University

Jixiang Wu

South Dakota State University

See next page for additional authors

Follow this and additional works at: https://newprairiepress.org/agstatconference

Part of the Agriculture Commons, and the Applied Statistics Commons

\section{(c) (1) $\Theta($}

This work is licensed under a Creative Commons Attribution-Noncommercial-No Derivative Works 4.0 License.

\section{Recommended Citation}

Appiah, Adams Kusi; Helget, Rebecca; Xu, Yi; and Wu, Jixiang (2014). "RESPONSE OF SOYBEAN YIELD AND YIELD COMPONENTS TO PHOSPHORUS FERTILIZATION IN SOUTH DAKOTA," Conference on Applied Statistics in Agriculture. https://doi.org/10.4148/2475-7772.1001

This Event is brought to you for free and open access by the Conferences at New Prairie Press. It has been accepted for inclusion in Conference on Applied Statistics in Agriculture by an authorized administrator of New Prairie Press. For more information, please contact cads@k-state.edu. 
Author Information

Adams Kusi Appiah, Rebecca Helget, Yi Xu, and Jixiang Wu 


\title{
Response of Soybean Yield and Yield Components to Phosphorus Fertilization in South Dakota
}

\author{
Adams Kusi Appiah', Rebecca Helget ${ }^{2}$, Yi Xu ${ }^{2}$, Nathan Mueller ${ }^{2}$, and Jixiang $\mathrm{Wu}^{2 *}$ \\ Department of Mathematics and Statistics ${ }^{1}$, Department of Plant Science ${ }^{2}$, South Dakota \\ State University, Brookings SD, 57007 USA
}

*: Contact Author (Jixiang.wu@sdstate.edu)

\begin{abstract}
Increased demand for soybean [Glycine max (L.) Merrill] production for industrial, human, and animal consumption has provided many incentives for farmers and producers to increase their production. In many soils used for soybean production, phosphorus (P) becomes a major limiting factor to soybean growth and grain production. A field experiment was conducted in five locations across Eastern South Dakota in 2013 to study the response of soybean yield and yield components to phosphorus fertilizer applications. The experiment was laid out in a randomized complete block (RCB) design with four replications. The treatments consisted of five P levels 0, 20, 40, 60, and 80lb/ac of triple superphosphate. Data for yield and yield components were collect and analyzed with several statistical methods including linear mixed model approaches and Additive Model and Multiplicative Interaction effect (AMMI) methods. There was no evidence showing that P had significant impacts on grain yield and yield components. P by environment (PE) interactions were not significant for all traits except whole pod weight. Large variation in yield and yield components were attributed to environmental conditions. Plant height, 100-pod weight, and seed weight of 100pod had positive and significant correlations with yield in three locations; Geddes, Mitchell, and Bancroft.
\end{abstract}

Keywords: Soybean, Phosphorus, AMMI, component, linear mixed model, variance components, MINQUE. 


\section{Introduction}

Soybean [Glycine max (L.) Merrill] is in high demand for both human and animal consumptions because of its nutritional values and potential use of biodiesel product. It has essential source of protein, oil and micronutrients in human and animal diets. Therefore, there are numerous incentives to increase soybean production to meet all these rising demand. Soybean is one of the most widely grown leguminous crops in the world (Guo et al. 2011). This crop is widely cultivated on world arable soils with low phosphorus (P). Investigation of soybean yield and related yield component traits with different $\mathrm{P}$ rates will help improve field management to optimize soybean production and seed quality.

Low $\mathrm{P}$ in soil is a major constraint for soybean growth and production, which are atmospheric nitrogen $\left(\mathrm{N}_{2}\right)$ dependent (Bordeleau and Prévost 1994) because $\mathrm{P}$ is particularly important for symbiotic $\mathrm{N}_{2}$ fixation in legumes (Zahran 1999). When $\mathrm{P}$ rate in soil is low, this process can be strongly undermined and thus becomes a principal yield-limiting nutrient (Pereira and Bliss 1989).

When P levels are inadequate, soybeans cannot grow and produce normally, or tolerate stresses as they should. Soybean is one of top crops grown in South Dakota; however, about 50\% of South Dakota soils is medium or low in P based on soil tests (Gelderman and Ulvestad 2011). Some farming practices that lead to P loss in soil negatively impact on soybean yield production. Therefore, to ensure profitable production of soybean, it is recommended that $\mathrm{P}$ should be returned to soil by adding wastes and/ or commercial fertilizers. The amount of $\mathrm{P}$ to be applied is based on the existing $\mathrm{P}$ and $\mathrm{pH}$ levels in the soil. Soil $\mathrm{pH}$ level provides an indication of the acidity or alkalinity of soil. Most leguminous plants require a neutral or slightly acidic soil for growth (Brockwell, Holliday, and Pilka 1991). Soybeans thrive in the $\mathrm{pH}$ range of 6.0 to 6.8. Soil P tests provide an indication of the level of soil $\mathrm{P}$ in plant. The test provides an index of $\mathrm{P}$ measurement that can be taken up by plant (Watson and Mullen 2007). The soil test supported by South Dakota State University recommendations is the Olsen sodium bicarbonate extraction method. The Olsen test predicts crop response in the soils within state boundaries of $\mathrm{pH}$ value ranging from below 5 to over 8 . The Olsen test results are well-correlated with crop response to P fertilization (Dahnke 1975). An Olsen $\mathrm{P}$ value of $10 \mathrm{mg} \mathrm{P} / \mathrm{kg}$ is generally considered to be optimum for plant growth 
(Kovar and Pierzynski 2009). Critical soil P concentrations indicate values above which fertilization no longer results in yield responses or economic benefits (Dodd and Mallarino 2005). Thus, at this point P fertilization is not recommended. South Dakota State University critical level for soybean is 15ppm Bray-P1, thus, non-fertilized yield almost equals to fertilized yield. Phosphorus efficiency in low soil P conditions may be related to an initial application of a large quantity of P fertilizer. Environmental factors such as temperature, rainfall, soil conditions, etc. may also play roles on soybeans plants effectively utilizing the applied chemical P in soil. On the other hand, because of both economic and environmental concerns, soil testing is becoming an increasingly important for crop-production systems (Beegle and Oravec 1990). Environmental concerns arise with regards to the volume of $\mathrm{P}$ applied to the soil to avoid run off into nearby streams.

Phosphorus is a non-mobile soil nutrient. This means that as a soil nutrient, it generally does not leach to groundwater. Moreover, applied P gets fixed immediately after application in acidic soils and the availability to the crop is low. In other situations, high P soil may not significantly influence yield unless accompanied by other practices to increase P uptake by the soybean plants. Although the total amount of $\mathrm{P}$ is high in some soils, $\mathrm{P}$ availability could be limited. This is because $\mathrm{P}$ forms insoluble precipitates with metals such as iron and aluminum in acid soils and calcium in alkaline soils (Sharpley et al. 1984, Sanyal and De Datta 1991). Moreover, P in soils can exist as organic P which is not directly available to plants as well (Iyamuremye, Baham, and Dick 1996). Soybeans response to fertilizers is affected by soil moisture as well (Kaspar, Timmons, and Zahler 1989). P by environment (PE) interaction effects could complicate soybean grain yield and thus investigation of PE interactions become very important.

The additive main effects and multiplicative interaction (AMMI) approach has been widely used to estimate yield stability and separate interaction effects between environment and genotypes in crop trials (Zobel, Gauch, and Wright 1988, Gauch and Zobel 1996, Crossa 1990). PE interactions in this study supported by South Dakota Soybean Research Promotion and Council could also be treated as interactions between environments and genotypes interaction so that we could apply the AMMI method to investigate potential PE interaction for yield and yield components. The main objectives of this study were to: (1) determine P and PE interaction effects 
on soybean grain yield and yield components and (2) determine which traits were significantly associated with yield at each of these locations.

\section{Materials and Methods}

An experiment was conducted at five locations: Geddes, Mitchell, Wessington Springs 1 (Groths), Wessington Springs 2 (Lutter), and Bancroft across Eastern South Dakota in 2013. The treatments consisted of five P levels $0,20,40,60$, and $80 \mathrm{lb} / \mathrm{ac}$ of triple superphosphate. The experiment in each location was laid out in a randomized complete block (RCB) design with four replications. Calibrated rates of $\mathrm{P}$ fertilizer were hand broadcasted into plots after planting. The seeding rate was approximately150,000 seed/ac and was sown in each 6-row plot with 5m in length and $75 \mathrm{~cm}$ between rows. Normal field practices were employed during the growing season at each location. Soil samples were collected before applying the P treatments. All plots were sampled by extracting soils from 0 to 6 inches deep. Soil test calibration levels for P used in South Dakota, ppm extractable (0-6 inches samples) is presented in (Table 1). The planting dates, temperature, and rainfall distribution patterns are presented in (Table 2).

\subsection{Data collection}

Prior to field harvest, we measured height of 10 normally developed plants (PH, inches) for each plot. In addition, we cut all dry plants of 1-m area in the middle of second or fifth row and saved these plants in one paper bag for each plot. In addition to 1-m population size, we measured the following traits: number of plants (NP/1-m), whole bag weight (WBW, g), and whole pod weight (WPW, g). Number of seed (NS/100-pod), 100-pod weight (HPW, g), and seed weight of 100-pod (SWHP, g) were determined by using 100 pods randomly selected from the 1-m sample for each plot. Grain yield (GY) were harvested from the third and fourth rows and then converted to bu/ac. 


\subsection{Statistical analysis}

Three types of analysis were conducted for the data: correlation analysis, linear model analysis, and AMMI analysis. The linear model was used to partition the variance into three components: P effects, environmental effects and PE effects. The linear mixed models, conditional and unconditional were used to estimate the variance components. The conditional linear model used the equation by (Zhu 1993, Wu et al. 2006). Before applying the conditional linear mixed model equation, extra variation contributed by yield component trait to grain yield was removed. Thus, the residual from linear regression was used as dependent variable. The variance component and standard errors of each parameter were estimated using minimum norm quadratic unbiased estimation (MINQUE) method (Rao 1971). The AMMI analysis was used to partition PE interaction effects. Correlation analysis was performed to reveal the relationship between grain yield and yield components by using Pearson’s simple correlation method.

$Y_{i j r}=\mu+P_{i}+E_{j}+P E_{i j}+E_{j(r)}+\varepsilon_{i j r} \ldots \ldots$.linear mixed model 1

$Y_{\left(G Y^{*}\right)}=\mathbf{1} \mu_{\left(G Y^{*}\right)}+\sum_{u=1}^{5} U_{u} \boldsymbol{e}_{u_{G Y^{*}}} \ldots \ldots . .$. conditional linear mixed model 2

$Y_{i j r}=\mu+P_{i}+E_{j}+\sum_{k=i} \lambda_{k} \alpha_{i k} \gamma_{j k}+r_{i j r} \ldots \ldots$.AMMI model 3

Where $Y_{i j r}$ is the yield and yield component of $i t h$ treatment in $j t h$ environment for $r t h$ replicate, $\mu$ is the total yield and yield component mean, $P_{i}$ is the main effect of Phosphorus, $E_{j}$ is the main effect of environment, $P E_{i j}$ is the interaction effects between phosphorus levels and environments, $\lambda_{k}$ is the square root of eigenvalue for kth component, $\alpha_{i k}$ is the principal component (PC) score of P level $i$ for $k t h$ component, $\gamma_{j k}$ is the PC score of environment $\mathrm{j}$ for $k t h$ component and $r_{i j r}$ is the residual error. $G Y^{*}$ is the residual from estimated linear regression when grain yield was regressed on each or all component traits. $e_{u}$ is the $u$ th vector of random effects, $U_{u}$ is the $u t h$ known design matrix for $e_{u}$.

For the purpose of estimating the variance components, location, treatment, and block effects within each location were treated as random variables. All statistical analyses were processed using R (R Core Team 2014). Linear model analyses were conducted using the $\mathrm{R}$ 
package minque (Wu 2014) by incorporating a group-based jackknife resampling approach with 10 randomly divided groups. AMMI biplots were generated by using the $\mathrm{R}$ package agricolae (Mendiburu 2014)

\section{Results and Discussions}

The soil samples from all locations showed that the soil $\mathrm{pH}$ values were within normal range for soybean growth. The soil $\mathrm{P}$ values showed that $\mathrm{P}$ was at medium level at all test locations except Bancroft. Therefore, fertilization was required for better soybean productions. However, high and above critical $\mathrm{P}$ rate was detected in Bancroft location. Weather conditions were similar between Mitchell and Geddes, and between Groths and Lutter (Table 2).

3.1. Mean performances of grain yield and yield component traits at different locations

Means for soybean grain yield and agronomic traits at each P level are presented in (Table 3). The location average grain yield ranged from the lowest of 40.0lbu/ac (Bancroft) to the highest of 56.87bu/ac (Groths). P rates varied from 47.45bu/ac (20lb/ac) to 48.42bu/ac (60lb/ac). The mean plant height varied from to 23.27inches (Bancroft) to 39.11inches (Mitchell). P rates recorded from 32.22inches (40lb/ac) to 33.92 inches (60lb/ac). For mean number of plants, location ranged from 9.3/1-m (Bancroft) to 22.5/1-m (Mitchell), whereas P rates varied from 18.5/1-m (0lb/ac) to 21.55/1-m (20lb/ac). Regarding whole bag weight (g/1-m), results indicated that mean values ranged from 490.91g (Bancroft) to 644.13g (Geddes). P rates recorded from $557.75 \mathrm{~g}(0 \mathrm{lb} / \mathrm{ac})$ to $606.54 \mathrm{~g}$ (80lb/ac). Whole pod weight recorded from 300.89g (Mitchel) to 401.96g (Groths). P rates varied from 340.25g (0lb/ac) to 371.38g (80lb/ac). The maximum number of seed was in Groths (259.85/100-pod) but the minimum was in Bancroft (205.75/100pod). P rates recorded from 237.10/100-pod (60lb/ac) to 244.05 (80lb/ac). The range of mean values for 100-pod weight and seed weight of 100-pod were from 34.44g and 23.03g in Mitchell to 48.88g and 34.22g in Lutter respectively. P rates recorded 43.34g and 30.93g (20lb/ac) to $44.48 \mathrm{~g}$ and 32.08g (80lb/ac) for 100-pod weight and seed of 100-pod weight respectively. Soybean grain yield and yield component responded differently to different P rates in each study location. For example, the highest yield in Groths (58.86bu/ac) and Lutter (50.21bu/ac) were obtained with 
0lb/ac, Bancroft (45.84bu/ac) was obtained with (20lb/ac), Geddes (53.46bu/ac) obtained with (40lb/ac), and Mitchell (46.54bu/ac) obtained with (80lb/ac).

\subsection{Analysis of variance for yield and yield components traits}

Analysis of variance results for soybean seed yield and agronomic traits across the five study sites obtained from this study are presented in (Table 4). No significant PE interactions were detected for these traits except whole pod weight. Location played a significant role on all test traits. No significant P effects were detected for yield and yield component traits. The results in (Table 4) suggested that soybean yield and yield component traits were more influenced by soil or weather conditions at these locations.

\section{3 . Variance components for yield and yield component traits}

An understanding of variability and the nature and extent of variance components are of fundamental importance especially in multi-environment studies. We were especially interested in determining the amount of contribution of location, P and PE interaction to grain yield and yield components traits. Assuming random effects of $\mathrm{P}$ and $\mathrm{E}$ made it possible to estimate various variance components. The variance components were estimated to assess the amount of variation contributing to variable (yield or a yield components trait) due to $\mathrm{P}$ treatment, location, $\mathrm{PE}$ interactions and random error. Environmental effect was significant for all traits except number of plants while P effect was insignificant for all traits. PE interaction was not significant for all traits except whole pod weight (Table 5). Most traits were more impacted by environmental effects while whole bag weight and whole pod weight were more influenced by random errors (Table 5).

\subsection{Conditional variance components for yield on yield component traits}

With linear mixed model approaches, we analyzed the relations between yield and yield component while with $\mathrm{P}, \mathrm{E}, \mathrm{PE}$, and block effects in the model. The conditional variance components were computed by first; performing simple linear regression of yield on each agronomic trait and then used the residuals as new dependent variable. Second; the conditional variance components were computed and the results reported in (Table 6). Results from simple 
linear regression (not shown here) indicated that number of seed, and whole pod weight were having significant association with yield at alpha level of 0.001 . Seed weight of 100-pods was significant at 0.01. Plant height, whole bag weight, and 100-pod weights were significant at 0.05. The slope of the number of plants was highly insignificant. Using the residuals from the estimated linear regression helped us to remove extra variation in yield accounted for by the given agronomic trait. For example, conditional environmental variance component for residuals from regressing grain yield on number of seed measures the environmental variance in the grain yield without the influence of number of seed. Compared to unconditional variance for grain yield, the conditional variances were either smaller or higher for some traits (Table 5 \& 6). For example 69.79\% (23.52/33.70) was not explained by the environmental effect for number of seed, while 54.03\% (18.21/33.70) of environmental variation was not explained by environmental effect for whole pod weight. For this given example, whole pod weight played more important role in grain yield as compared to number of seed. When multiple linear regression was estimated with all component traits included, the results (not shown here) indicated that the slopes of plant height, 100-pod weight, and seed weight of 100-pod were highly significant with yield. Number of seed and whole pod weight were significant at 0.01 . Whole bag weight was significant whilst number of plants was not significant at 0.05 . The residual from the estimated multiple regressions was used for conditional variance component estimation and the results reported in (Table 7). The conditional environmental variance was smaller as compared to the unconditional environmental variance for yield. Thus 28.31\% (9.53/33.70) of environmental variation in yield was not explained by all component traits together.

The variance component estimates for environment exceeding random error for most of the traits implied that yield and yield components were affected by environment where the biggest variations came from. Lower conditional variance for some tested traits as compared to unconditional yield variance suggests that these traits have contribution to grain yield.

3.5. Correlation coefficients analysis 
Correlation coefficients were measured between yield and agronomic traits, and yield and soil $\mathrm{P}$ and $\mathrm{pH}$ values for each location and are presented in (Table 8). Grain yield had significant negative correlation with $\mathrm{pH}$ value in Geddes and Mitchell. $\mathrm{P}$ values had a significant negative correlation with yield in Bancroft only. In Geddes, plant height ( $\mathrm{r}=0.78), 100$-pod weight ( $\mathrm{r}=0.54)$, and seed weight of 100-pod ( $r=0.62)$ were significantly and positively correlated with yield. In Mitchell, yield had significant and positive correlation with plant height ( $\mathrm{r}=0.59)$, number of seed (0.46), 100-pod weight ( $\mathrm{r}=0.81$ ), and seed weight of 100-pod ( $\mathrm{r}=0.86)$. In Bancroft, yield had a significant and positive correlation with plant height ( $\mathrm{r}=0.65)$, number of seed $(\mathrm{r}=0.59)$, whole pod weight ( $\mathrm{r}=0.45)$, 100-pod weight $(\mathrm{r}=0.48)$, and seed weight of 100 -pod $(\mathrm{r}=0.56)$. While in the other two locations (Lutter and Groths), no significant correlations were detected between yield and yield components.

A difference in correlation pattern was observed for different locations. For example, yield had positive correlation with plant height in Geddes while it was not correlated with plant height in Groths or Lutter. This differential correlation pattern will help farmer and producers to adopt different management practices to increase grain yield in their respective locations.

\subsection{AMMI analyses of PE interaction effects}

AMMI analyses were used to graphically visualize PE interaction for soybeans grain yield and traits that had significant PE effects. To investigate the main effects and interactions across environments, AMMI biplots 1 and 2 were constructed for yield and whole pod weight.

The graphical representation of AMMI1 analysis reveals the main effect means on the abscissa and first principal component (PC1) scores of both P and environments simultaneously on the ordinate.

AMMI 2 biplot which plots principal component (PC) 1 versus PC 2 explains the magnitude of interaction of each $\mathrm{P}$ level and environment. The AMMI 2 biplot helps in the visual interpretation of interaction effects of $\mathrm{P}$ levels in each environment and identified $\mathrm{P}$ levels that suited for specific environmental conditions.

Yield 
AMMI 1 biplots showing main effects of soybean grain yields versus PC1 scores are presented in (Figure 1). According to (Figure 1), 0lb/ac and 60lb/ac P levels had higher grain yield more than the mean yield and were more suitable for Groths and Geddes locations but with negative PC1 scores. The treatment of levels 40lb/ac and 20lb/ac of P exhibited the same main effect as well as 0lb/ac and 60lb/ac. The environments, Geddes and Groths were the highest yielding with Groths more interactive reflected with high PC1 scores hence, was most suitable for specific P levels. In relation to the environments, the graph showed that environmental conditions in Mitchell and Lutter influenced the PE interaction of soybean grain yield in a lower proportion, reflected in the lower magnitude of PC1 scores.

AMMI2 biplots showing PC1 and PC2 scores of P levels and locations are presented in (Figure 1). The first two PC scores explained $59 \%$ and 33\% of total PE interaction variation of yield respectively. When a P level and environment are in the same quadrant, they have positive interaction. For example, 0lb/ac and 80lb/ac showed positive interactions with Lutter and Groths (Figure 1). In addition, 40lb/ac and 40lb/ac displayed positive interactions with Geddes. Distribution of P levels points in the AMMI2 biplot revealed that all the P levels scattered further away from the origin, indicating high interaction of these P levels with environments.

\section{Whole pod weight}

From the AMMI 1(Figure 2), the analysis of $\mathrm{P}$ main effect showed that 80lb/ac had the highest whole pod weight. In relation to environments, Geddes and Groths were the highest yielding and more interactive P treatment. From the AMM1 biplot, 40lb/ac and 80lb/ac performed best in Geddes. Both the environments and P treatments differed in main and interaction effects.

The AMM2 biplot explained $88.8 \%$ of the PE interaction variation in the whole bag weight. Phosphorus levels of 20lb/ac and 60lb/ac had best performance in Groths and Mitchell whereas 40lb/ac was in Geddes.

Many confounding factors may have impacted on the P levels not to significantly influence soybean grain yield and yield component traits. Environmental factors such as Rainfall, soil conditions, temperature, is among several factors that played some roles for soybeans plants not 
effectively utilizing the applied P. Genotypic effects could also be another contributing factor as different genotypes were used.

\section{Summary}

The present study was conducted to determine the response of soybean grain yield and yield component traits to phosphorus fertilizations. Our study showed that P effects were not significant for yield or yield components. It appeared that these traits were significantly impacted by environmental conditions while PE interaction effects were not significant for yield or yield components except whole pod weight. The highest positive correlation between yield and plant height was in Geddes. The AMMI analyses were conducted for yield and whole pod weight. The PC1 score had a significant interaction effect and explained 68\% of the total interaction variations for whole pod weight. In this study, locations were relatively more important than P levels for yield and yield components to response to applied P in Eastern South Dakota State. Investment should be in increasing locations to increase the number of environments as to enhance experimental precision.

These results in this study could change with respect to the kind of genotype used, previous crop cultivated, current and previous management practices by cooperators and time, therefore further research is needed regarding the potential of P needs of soybeans.

Table 1. Soil Test for P Calibration Levels Used in South Dakota 


\begin{tabular}{|c|c|c|c|c|c|c|}
\hline \multicolumn{6}{|c|}{ Categories } & \multirow{3}{*}{ Very High } \\
\hline Nutrient & Soil tes & Very Low & Low & Medium & & \\
\hline & & & n extractable & (0-6 inch samp & & \\
\hline P (ppm) & Bray P. & $10-5$ & $6-10$ & $11-15$ & -20 & \multirow{2}{*}{$\begin{array}{l}21+ \\
16+\end{array}$} \\
\hline $\mathrm{P}(\mathrm{ppm})$ & Olsen & $0-3$ & $4-7$ & $8-11$ & -15 & \\
\hline \multicolumn{7}{|c|}{$\begin{array}{l}\text { Source: Fertilizer Recommendation Guide, September 2005, Plant Science Department South } \\
\text { Dakota State University }\end{array}$} \\
\hline \multicolumn{7}{|c|}{$\begin{array}{l}\text { Table } 2 \text {. Temperature, status of rainfall, relative humidity, soil properties, latitude, altitude and } \\
\text { code for each test environment is given. }\end{array}$} \\
\hline \multicolumn{7}{|c|}{ Location } \\
\hline \multicolumn{2}{|c|}{$\begin{array}{l}\text { Environmental } \\
\text { Factors }\end{array}$} & Bancroft & Geddes & Groths & Lutter & Mitchell \\
\hline \multirow{3}{*}{\multicolumn{2}{|c|}{$\begin{array}{l}\text { Temp (Max) } \\
\text { Temp(Min) } \\
\text { Rainfall(in) }\end{array}$}} & 79.4 & 80 & & & 80 \\
\hline & & 55.8 & 57.4 & & & 57.4 \\
\hline & & 0.096 & 0.11 & & & 0.11 \\
\hline \multirow{2}{*}{\multicolumn{2}{|c|}{$\begin{array}{l}\text { Soil pH (ppm) } \\
\text { Soil P (Olsen, ppm) }\end{array}$}} & 6.1 & 6.3 & 6.3 & 6.1 & 5.7 \\
\hline & & 19 & 10 & 9 & 7 & 11 \\
\hline \multicolumn{2}{|l|}{ Latitude } & $44.5 \mathrm{~N}$ & $43.33 N$ & $44.01 \mathrm{~N}$ & $44.01 \mathrm{~N}$ & $43.56 \mathrm{~N}$ \\
\hline \multirow{2}{*}{\multicolumn{2}{|c|}{$\begin{array}{l}\text { Longitude } \\
\text { Planting Date }\end{array}$}} & $-97.77 \mathrm{~W}$ & $-98.68 \mathrm{~W}$ & $-98.89 \mathrm{~W}$ & $-98.83 \mathrm{~W}$ & $-98.11 \mathrm{~W}$ \\
\hline & & Jun-5-2013 & Jun-4-2013 & May-9-2013 & Jun-4-2013 & May-13-2013 \\
\hline
\end{tabular}


Table 3. Mean grain yield and yield component traits of $\mathrm{P}$ levels from each of the five locations across Eastern South Dakota 2013.

\begin{tabular}{|c|c|c|c|c|c|c|c|c|}
\hline \multicolumn{9}{|c|}{ Location = Bancroft } \\
\hline \multicolumn{9}{|c|}{ Traits } \\
\hline $\begin{array}{c}\mathrm{P} \\
\text { treatment }\end{array}$ & $\begin{array}{l}\text { GY } \\
\text { (bu/ac) }\end{array}$ & $\begin{array}{l}\mathrm{PH} \\
\text { (Inches) }\end{array}$ & NP & $\begin{array}{l}\text { WBW } \\
\text { (g) }\end{array}$ & $\begin{array}{l}\text { WPW } \\
\text { (g) }\end{array}$ & NS & $\begin{array}{l}\text { HPW } \\
\text { (g) }\end{array}$ & $\begin{array}{l}\text { SWHP } \\
\text { (g) }\end{array}$ \\
\hline 0lb/ac & 38.41 & 22.93 & 20.75 & 486.88 & 327.88 & 239.00 & 47.12 & 34.80 \\
\hline 20lb/ac & 45.84 & 22.88 & 21.25 & 510.48 & 360.20 & 237.75 & 47.25 & 34.50 \\
\hline $40 \mathrm{lb} / \mathrm{ac}$ & 38.80 & 23.04 & 18.75 & 446.05 & 305.73 & 231.25 & 45.17 & 32.70 \\
\hline 60lb/ac & 37.85 & 23.94 & 21.25 & 463.52 & 311.27 & 234.75 & 46.58 & 33.48 \\
\hline $80 \mathrm{lb} / \mathrm{ac}$ & 39.16 & 23.57 & 23.50 & 547.60 & 389.75 & 239.00 & 48.38 & 35.30 \\
\hline mean & 40.012 & 23.27 & 21.10 & 490.91 & 338.97 & 236.35 & 46.90 & 34.16 \\
\hline \multicolumn{9}{|l|}{ Groths } \\
\hline 0lb/ac & 58.86 & 28.47 & 19.50 & 597.12 & 425.62 & 260.00 & 46.67 & 34.33 \\
\hline 20lb/ac & 51.10 & 28.10 & 20.25 & 584.83 & 417.57 & 257.50 & 46.08 & 33.62 \\
\hline 40lb/ac & 57.31 & 28.54 & 21.75 & 545.23 & 386.23 & 263.50 & 48.23 & 35.85 \\
\hline 60lb/ac & 58.52 & 29.29 & 19.50 & 565.75 & 399.48 & 261.75 & 45.35 & 33.48 \\
\hline $80 \mathrm{lb} / \mathrm{ac}$ & 58.54 & 28.38 & 18.50 & 544.08 & 380.88 & 256.50 & 45.25 & 33.20 \\
\hline mean & 56.866 & 28.556 & 19.9 & 567.402 & 401.956 & 259.85 & 46.316 & 34.096 \\
\hline \multicolumn{9}{|l|}{ Geddes } \\
\hline 0lb/ac & 48.75 & 38.29 & 12.25 & 564.65 & 305.48 & 243.25 & 41.92 & 30.62 \\
\hline 20lb/ac & 48.73 & 37.03 & 17.50 & 639.95 & 363.60 & 240.75 & 41.90 & 30.55 \\
\hline 40lb/ac & 53.12 & 38.38 & 18.75 & 697.30 & 451.50 & 238.50 & 44.08 & 32.20 \\
\hline $60 \mathrm{lb} / \mathrm{ac}$ & 53.46 & 39.49 & 20.50 & 624.75 & 349.75 & 242.50 & 42.60 & 31.27 \\
\hline $80 \mathrm{lb} / \mathrm{ac}$ & 44.93 & 35.61 & 17.75 & 694.02 & 406.57 & 247.25 & 43.58 & 31.52 \\
\hline mean & 49.80 & 37.76 & 17.35 & 644.13 & 375.38 & 242.45 & 42.82 & 31.23 \\
\hline \multicolumn{9}{|l|}{ Lutter } \\
\hline 0lb/ac & 50.21 & 37.26 & 22.5 & 533.42 & 332.38 & 246.50 & 49.23 & 34.92 \\
\hline 20lb/ac & 45.73 & 36.21 & 22.50 & 547.83 & 301.55 & 246.50 & 47.27 & 32.85 \\
\hline 40lb/ac & 44.34 & 36.19 & 22.50 & 616.83 & 355.15 & 249.00 & 47.38 & 32.7 \\
\hline 60lb/ac & 46.95 & 37.35 & 21.75 & 595.58 & 335.23 & 248.25 & 49.15 & 34.58 \\
\hline $80 \mathrm{lb} / \mathrm{ac}$ & 45.72 & 37.70 & 23.25 & 618.27 & 390.43 & 255.00 & 51.35 & 36.05 \\
\hline mean & 46.59 & 36.94 & 22.5 & 582.39 & 342.95 & 249.05 & 48.88 & 34.22 \\
\hline \multicolumn{9}{|l|}{ Mitchell } \\
\hline 0lb/ac & 45.60 & 38.31 & 17.75 & 606.65 & 309.90 & 197.00 & 33.55 & 22.32 \\
\hline 20lb/ac & 45.85 & 37.06 & 26.25 & 671.48 & 320.20 & 206.00 & 34.23 & 23.12 \\
\hline 40lb/ac & 45.15 & 39.95 & 18.25 & 644.92 & 284.88 & 205.00 & 33.95 & 22.20 \\
\hline 60lb/ac & 45.33 & 39.54 & 19.25 & 649.83 & 300.23 & 198.25 & 34.73 & 23.18 \\
\hline $80 \mathrm{lb} / \mathrm{ac}$ & 46.54 & 40.69 & 23.50 & 628.73 & 289.25 & 222.50 & 35.73 & 24.32 \\
\hline \multirow[t]{2}{*}{ mean } & 45.69 & 39.11 & 21 & 640.32 & 300.89 & 205.75 & 34.44 & 23.03 \\
\hline & & & P-rate & & & & & \\
\hline $0 \mathrm{lb} / \mathrm{ac}$ & 48.37 & 33.05 & 18.55 & 557.75 & 340.25 & 237.15 & 43.70 & 31.40 \\
\hline 20lb/ac & 47.45 & 32.26 & 21.55 & 590.91 & 352.62 & 237.70 & 43.34 & 30.93 \\
\hline
\end{tabular}




\begin{tabular}{lllllllll}
\hline 40lb/ac & 47.74 & 33.22 & 20.00 & 590.07 & 356.69 & 237.45 & 43.76 & 31.13 \\
60lb/ac & 48.42 & 33.92 & 20.45 & 579.88 & 339.19 & 237.10 & 43.68 & 31.20 \\
80lb/ac & 46.98 & 33.19 & 21.3 & 606.54 & 371.38 & 244.05 & 44.86 & 32.08 \\
\hline
\end{tabular}

$\mathrm{P}=$ Treatment (Phosphorus levels), GY=grain yield, $\mathrm{PH}=$ plant height, $\mathrm{NP}=$ number of plants, WBW= whole bag weight, WPW=whole pod weight, NS=number of seed, HPW=100-pod weight, SWHP=seed weight of 100-pod, mean=environmental mean

Table 4. Mean square values from combined analysis of variance of five treatments across five locations

\begin{tabular}{|c|c|c|c|c|c|c|c|c|c|}
\hline \multirow[t]{2}{*}{ SOV } & \multirow{2}{*}{$\begin{array}{l}\mathrm{D} \\
\mathrm{F}\end{array}$} & \multicolumn{8}{|c|}{ Mean Sum of Squares of traits } \\
\hline & & $\begin{array}{l}\mathrm{GY} \\
\text { (Bu/ac) }\end{array}$ & $\begin{array}{l}\mathrm{PH} \\
\text { (Inches) }\end{array}$ & NS & NP & $\begin{array}{l}\text { WBW } \\
\text { (g) }\end{array}$ & $\begin{array}{l}\text { WPW } \\
\text { (g) }\end{array}$ & $\begin{array}{l}\text { HPW } \\
\text { (g) }\end{array}$ & $\begin{array}{l}\text { SWHP } \\
\text { (g) }\end{array}$ \\
\hline $\mathrm{E}$ & 4 & $\begin{array}{l}763.8 * * \\
*\end{array}$ & $\begin{array}{l}949.2^{* *} \\
*\end{array}$ & $\begin{array}{l}8299 * * \\
*\end{array}$ & $\begin{array}{l}74.04 * * \\
*\end{array}$ & $\begin{array}{l}78639 * * \\
*\end{array}$ & $\begin{array}{l}29531^{* *} \\
*\end{array}$ & $\begin{array}{l}651.7 * * \\
*\end{array}$ & $\begin{array}{l}464.4^{* *} \\
*\end{array}$ \\
\hline $\mathrm{P}$ & 4 & 7.6 & 7.00 & 181 & 28.57 & 6468 & 3500 & 6.6 & 3.9 \\
\hline $\mathrm{P} \times \mathrm{E}$ & 16 & 37.5 & 3.4 & 101 & 20.73 & 5687 & $5153 * *$ & 5.6 & 4.5 \\
\hline $\begin{array}{l}\text { Bloc } \\
\mathrm{k}\end{array}$ & 15 & $75.8 * *$ & 7.3 & 196 & 5.89 & 6442 & 1960 & $28.3^{* *}$ & $23 * *$ \\
\hline $\begin{array}{l}\text { Error } \\
\mathrm{S}\end{array}$ & 60 & 25.1 & 4.4 & 128 & 13.22 & 6045 & 2164 & 11.8 & 8.8 \\
\hline
\end{tabular}

SOV= source of variations, $\mathrm{DF}=$ degrees of freedom, $\mathrm{E}=$ environment, $\mathrm{P}=$ Treatment (Phosphorus levels), GY=grain yield, $\mathrm{PH}=$ plant height, $\mathrm{NP}=$ number of plants, WBW= whole bag weight, WPW=whole pod weight, NS=number of seed, HPW=100-pod weight, SWHP=seed weight of 100-pod

**, *** are significant at probability levels of 0.01 and 0.00 respectively.

Table 5. Estimated variance components for each of eight soybean trait

\begin{tabular}{|l|l|l|l|l|l|l|l|l|}
\hline $\mathrm{V}$ & $\mathrm{SY}$ & $\mathrm{PH}$ & $\mathrm{NS}$ & $\mathrm{NP}$ & WBW & WPW & HPW & SWHP \\
\hline $\mathrm{V}_{\mathrm{P}}$ & 0.00 & 0.18 & 4.27 & 0.52 & 101.85 & 5.99 & 0.11 & 0.02 \\
\hline $\mathrm{V}_{\mathrm{E}}$ & $33.70^{* * *}$ & $47.14 * * *$ & $405.11^{* * *}$ & 3.00 & $3635.06^{* *}$ & $1243.21^{* * *}$ & $31.51^{* * *}$ & $22.13^{* * *}$ \\
\hline $\mathrm{V}_{\mathrm{PE}}$ & 3.17 & 0.13 & 1.32 & 1.83 & 222.27 & $745.99^{* *}$ & 0.00 & 0.01 \\
\hline $\mathrm{V}_{\mathrm{B}}$ & 10.23 & 0.55 & 15.01 & 0 & 190.69 & 18.83 & $3.29 * * *$ & 2.85 \\
\hline $\mathrm{V}_{\mathrm{e}}$ & $25.01^{* *}$ & $4.43^{* * *}$ & $127.76^{* * *}$ & $13.15^{* * *}$ & $6044.13^{* * *}$ & $2155.99^{* * *}$ & 11.82 & $8.78^{* * *}$ \\
\hline
\end{tabular}

$\mathrm{V}=$ variance component, $\mathrm{V}_{\mathrm{E}}=$ environment variance, $\mathrm{V}_{\mathrm{P}}=$ Treatment (Phosphorus levels) variance, $V_{\mathrm{PE}}=$ phosphorus by environment interaction variance, $\mathrm{V}_{\mathrm{B}}=$ blocking with environment variance, $\mathrm{V}_{\mathrm{e}}=$ error variance, $\mathrm{GY}=$ grain yield, $\mathrm{PH}=$ plant height, $\mathrm{NP}=$ number of plants, $\mathrm{WBW}=$ whole bag weight, WPW=whole pod weight, NS=number of seed, HPW=100-pod weight, SWHP=seed weight of 100-pod, Est. = estimate

$* *, * * *$ are significant at probability levels of 0.01 and 0.00 respectively. 
Table 6. Estimated conditional variance components of soybean grain yield when each component trait was in the model

\begin{tabular}{|l|l|l|l|l|l|}
\hline $\begin{array}{l}\text { Trait } \\
\text { conditioned }\end{array}$ & \multicolumn{5}{l|}{ Conditional variance components } \\
\hline & $\mathrm{V}_{\mathrm{P}}$ & $\mathrm{V}_{\mathrm{E}}$ & $\mathrm{V}_{\mathrm{PE}}$ & $\mathrm{V}_{\mathrm{B}}$ & $\mathrm{V}_{\mathrm{e}}$ \\
\hline PH & 0.00 & $34.26^{* * *}$ & 3.17 & $8.57^{* *}$ & $22.91^{* * *}$ \\
\hline NS & 0.00 & $23.52^{* * *}$ & 4.13 & $6.20^{*}$ & $22.90^{* * *}$ \\
\hline NP & 0.00 & $33.39^{* * *}$ & 3.09 & $10.29^{*}$ & $25.23^{* * *}$ \\
\hline WBW & 0.01 & $29.68^{* * *}$ & 3.77 & $9.42^{*}$ & $24.59^{* * *}$ \\
\hline WPW & 0.10 & $18.21^{* * *}$ & $5.53^{*}$ & $5.27^{*}$ & $25.69^{* * *}$ \\
\hline HPW & 0.00 & $36.38^{* * *}$ & $3.26+$ & $6.87+$ & $22.26^{* * *}$ \\
\hline SWHP & 0.00 & $36.05^{* * *}$ & 3.08 & $5.71^{* *}$ & $21.29^{* * *}$ \\
\hline
\end{tabular}

$\mathrm{V}=$ variance component, $\mathrm{V}_{\mathrm{E}}=$ environment variance, $\mathrm{V}_{\mathrm{P}}=$ Treatment (Phosphorus levels) variance, $\mathrm{V}_{\mathrm{PE}}=$ phosphorus by environment interaction variance, $\mathrm{V}_{\mathrm{B}}$ =blocking with environment variance, $\mathrm{V}_{\mathrm{e}}=$ error variance, $\mathrm{GY}=$ grain yield, $\mathrm{PH}=$ plant height, $\mathrm{NP}=$ number of plants, WBW= whole bag weight, WPW=whole pod weight, NS=number of seed, HPW=100-pod weight, SWHP=seed weight of 100-pod, Mu=overall mean

$+, *, * *, * * *$ are significant at probability levels of $0.1,0.05,0.01$ and 0.001 respectively.

Table 7. Estimated conditional variance component and standard error when all were all component trait included were in the model

\begin{tabular}{|l|l|l|l|}
\hline Variance & Estimate & Standard error & P-value \\
\hline$V_{P}$ & 0.18 & 0.31 & 0.9336 \\
\hline$V_{E}$ & 9.53 & 1.16 & 0.0001 \\
\hline$V_{P E}$ & 1.45 & 1.47 & 0.7888 \\
\hline$V_{B}$ & 0.93 & 1.33 & 0.9007 \\
\hline$V_{e}$ & 19.74 & 2.51 & 0.0001 \\
\hline
\end{tabular}

$\mathrm{V}=$ variance component, $\mathrm{V}_{\mathrm{E}}=$ environment variance, $\mathrm{V}_{\mathrm{P}}=$ Treatment (Phosphorus levels) variance, $\mathrm{V}_{\mathrm{PE}}=$ phosphorus by environment interaction variance, $\mathrm{V}_{\mathrm{B}}=$ blocking with environment variance, $\mathrm{V}_{\mathrm{e}}=$ error variance 
Table 8. Correlation coefficient between yield and yield component traits, and soil conditions across five locations

\begin{tabular}{llllll}
\hline Traits & Gedde & Groths & $\begin{array}{c}\text { Mitchell } \\
\text { Yield }\end{array}$ & Lutter & Bancroft \\
Oslen-P & 0.03 & -0.24 & -0.01 & -0.03 & $-0.53^{*}$ \\
pH & $-0.54^{*}$ & 0.15 & $-0.49^{*}$ & -0.21 & 0.34 \\
Plant height & $0.78^{*}$ & 0.18 & $0.59^{*}$ & 0.16 & $0.65^{*}$ \\
Number of seed & 0.32 & 0.16 & $0.46^{*}$ & 0.17 & $0.59^{*}$ \\
Number of plants & 0.19 & -0.13 & 0.29 & 0.37 & 0.03 \\
Whole bag weight & -0.04 & 0.1 & 0.19 & 0.12 & 0.44 \\
Whole pod weight & 0.26 & 0.08 & 0.37 & 0.15 & $0.45^{*}$ \\
100-pod weight & $0.54^{*}$ & 0.16 & $0.81^{*}$ & 0.37 & $0.48^{*}$ \\
Seed weight of 100-pod & $0.62^{*}$ & 0.17 & $0.86^{*}$ & 0.42 & $0.56^{*}$ \\
\hline
\end{tabular}

* is significant at probability levels of 0.05 


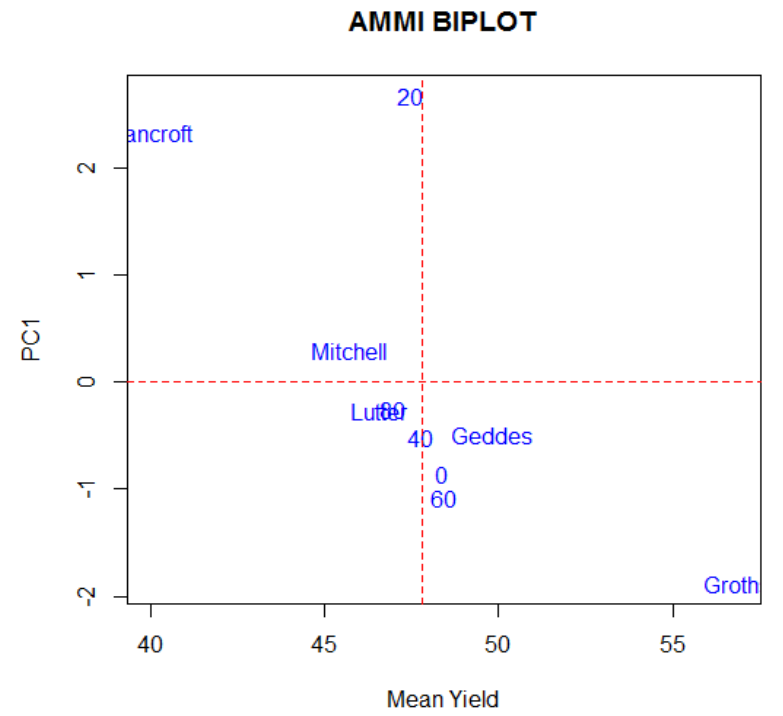

AMMI1 biplot

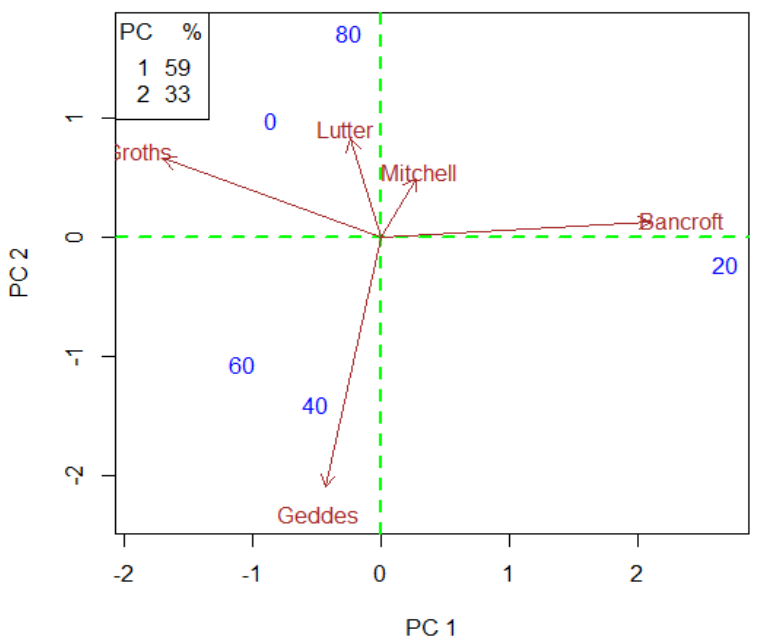

AMMI 2 biplot

Fig 1. Graphic displays of $\mathrm{P}$ and $\mathrm{E}$ in an AMMI biplot for yield performance in five environments (locations) AMMI 1; biplot of the first principal component (PC1) scores versus mean yield. AMMI2; biplot of the first principal component (PC1) versus the second principal component (PC2) for soybeans

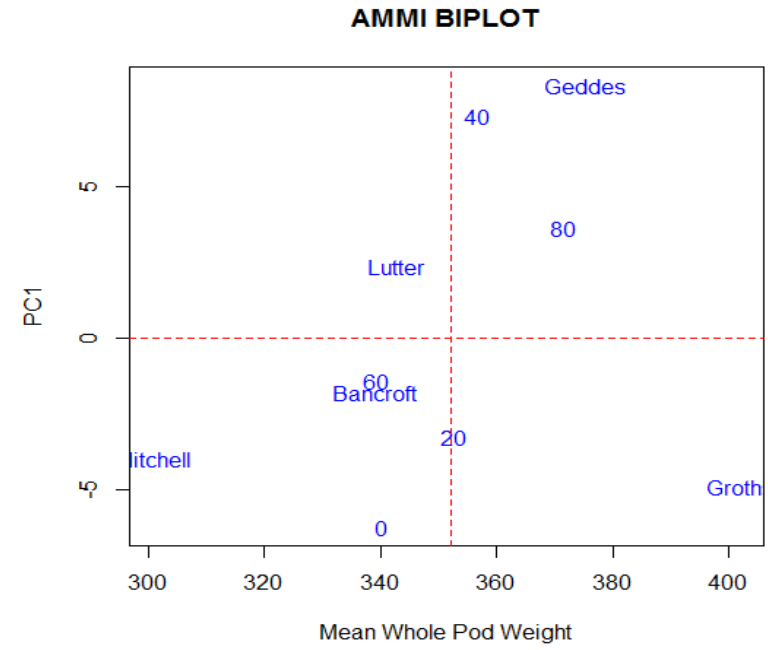

AMMI 1 biplot

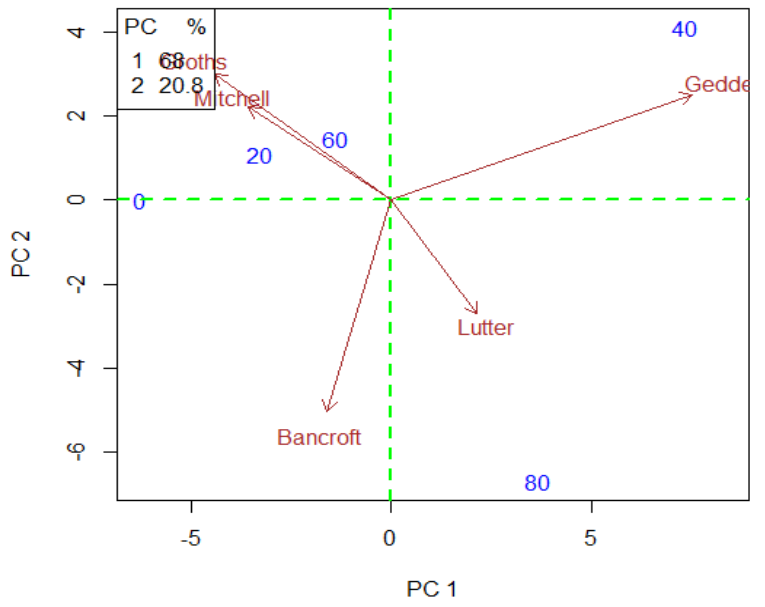

AMMI 2 biplot

Fig 2. Graphic displays of $\mathrm{P}$ and $\mathrm{E}$ in an AMMI biplot for whole pod weight performance in five environments (locations). AMMI 1; biplot of the first principal component (PC1) scores versus mean whole pod weight. AMMI2; biplot of the first principal component (PC1) versus the second principal component (PC2) for soybeans 


\section{REFERENCES}

Beegle, DB, and TC Oravec. 1990. "Comparison of field calibrations for mehlich $3 \mathrm{P}$ and $\mathrm{K}$ with Bray-Kurtz $\mathrm{P} 1$ and ammonium acetate $\mathrm{K}$ for corn." Communications in Soil Science \& Plant Analysis no. 21 (13-16):1025-1036.

Bordeleau, LM, and Danielle Prévost. 1994. "Nodulation and nitrogen fixation in extreme environments." In Symbiotic Nitrogen Fixation, 115-125. Springer.

Brockwell, J., R. A. Holliday, and A. Pilka. 1991. "Soil pH is a major determinant of the numbers of naturally occurrin g Rhizobium meliloti in non-cultivated soils in central New South Wales." Australian journal of experimental agriculture no. 31 (2):211-219.

Crossa, J. 1990. "Statistical analyses of multilocation trials." Advances in agronomy no. 44:55-85.

Dahnke, William C. 1975. "Recommended chemical soil test procedures for the North Central Region. introduction." Bull Dep Agric Econ ND Agric Exp Stn ND State Univ Agric Appl Sci.

Dodd, J. R., and A. P. Mallarino. 2005. "Soil-test phosphorus and crop grain yield responses to long-term phosphorus fertilization for corn-soybean rotations." Soil Science Society of America Journal no. 69 (4):1118-1128. doi: 10.2136/sssaj2004.0279.

Gauch, H.G. Jr., and R.W. Zobel. 1996. " AMMI analysis of yield trials." In Genotype -by- environment interaction

edited by Hugh G. Gauch and Manjit S. Kang. Boca Raton : CRC Press, c1996.

Gelderman, R., and L. Ulvestad. 2011. "A summary of soil test results (July 2009 - June 2010). Soil PR 105. Soil/Water Research, PI. Sci. Paml. 30 (Revised 2011). Brookings: SDAES." TB (South Dakota Agricultural Experiment Station) TB $(99$, rev.).

Guo, Wenbing, Xiaolong Yan, Hong Liao, Lu Qin, Jing Zhao, and Xinxin Li. 2011. "A soybean Îø-expansin gene GmEXPB2 intrinsically involved in root system architecture responses to abiotic stresses [electronic resource]." Plant journal no. 66 (3):541-552. doi: http://dx.doi.org/10.1111/j.1365313X.2011.04511.x.

Iyamuremye, F., J. Baham, and R. P. Dick. 1996. "Organic amendments and phosphorus dynamics. II. Distribution of soil phosphorus fractions." Soil science no. 161 (7):436-443.

Kaspar, T. C., D. R. Timmons, and J. B. Zahler. 1989. "Soybean response to phosphorus and potassium fertilizers as affected by soil drying." Soil Science Society of America journal no. 53 (5):14481454. 
Kovar, John L, and Gary M Pierzynski. 2009. "Methods of phosphorus analysis for soils, sediments, residuals, and waters second edition." Southern cooperative series bulletin (408).

Mendiburu, Felipe de. 2014. "agricolae: Statistical Procedures for Agricultural Research."

Pereira, P. A. A., and F. A. Bliss. 1989. "Selection of common bean (Phaseolus vulgaris L.) for N2 fixation at different levels of available phosphorus under field and environmentally-controlled conditions." Plant and Soil no. 115 (1):75-82. doi: 10.1007/BF02220696.

R: A Language and Environment for Statistical Computing R version 3.1.1 (2014-07-10) R Foundation for Statistical Computing.

Rao, C Radhakrishna. 1971. "Estimation of variance and covariance components-MINQUE theory." Journal of multivariate analysis no. 1 (3):257-275.

Sanyal, SK, and SK De Datta. 1991. "Chemistry of phosphorus transformations in soil." In Advances in Soil Science, 1-120. Springer.

Sharpley, A. N., A. C. Mathers, B. A. Stewart, and S. J. Smith. 1984. "Forms of phosphorus in soil receiving cattle feedlot waste [electronic resource]." Journal of environmental quality no. 13 (2):211-215. doi: http://hdl.handle.net/10113/19842.

Watson, Maurice, and Robert Mullen. 2007. "Understanding Soil Tests for Plant-Available Phosphorus." Fact Sheet, School of Environment and Natural Resources:1-4.

Wu, Jixiang. 2014. "minque: An R Package for Linear Mixed Model Analyses " Package 'minque'.

Wu, Jixiang, Dongfeng Wu, Johnie N Jenkins, and Jack C McCarty Jr. 2006. "A recursive approach to detect multivariable conditional variance components and conditional random effects." Computational statistics \& data analysis no. 50 (2):285-300.

Zahran, Hamdi Hussein. 1999. "Rhizobium-legume symbiosis and nitrogen fixation under severe conditions and in an arid climate." Microbiology and molecular biology reviews no. 63 (4):968989.

Zhu, Jun. 1993. "General genetic models and new analysis methods for quantitative traits." Acta Agriculturae Universitatis Chekianensis no. 20 (6):551-559.

Zobel, R. W., H. G. Gauch, Jr., and M. J. Wright. 1988. "Statistical analysis of a yield trial." Agronomy journal no. 80 (3):388-393. 